\title{
A comparative study of catastrophic health expenditure in Zhejiang and Qinghai province, China
}

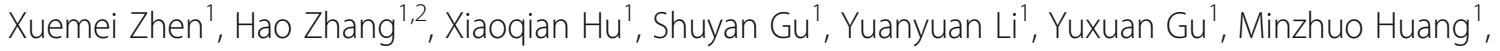

Xueshan Sun ${ }^{1}$, Jingming Wei ${ }^{1}$ and Hengjin Dong ${ }^{1 *}$ (D)

\begin{abstract}
Background: China has made great achievements in health insurance coverage and healthcare financing; however, the rate of catastrophic health expenditure (CHE) was 13.0\% in China in 2008, which is higher than that in some other countries. There remain some differences in life-style, national customs, medical conditions, and health consciousness in different provinces in China. This study aimed to compare the rates of households with CHE, further to explore the different performance of factors influencing CHE between Zhejiang and Qinghai province, China.

Methods: Data were derived from the household surveys conducted in Zhejiang and Qinghai. Sampling on multistage stratified cluster random method was adopted. Household with CHE occurs when the out-of-pocket payment for health care equals to or exceeds $40 \%$ of a household's income. Univariate and multivariate logistic regression analyses were used to identify the performance of factors of $\mathrm{CHE}$.

Results: A total of 1598 households were included in this study, including 995 in Zhejiang and 603 in Qinghai. The average rates of CHE in Zhejiang and Qinghai were 9.6 and 30.5\%, respectively. We found that economic status of households and households headed by an employed person are the protective factors for $\mathrm{CHE}$; and number of members with chronic diseases and number of inpatients in household are the risk factors for CHE in the two provinces. Besides, poor/low-insured households in Zhejiang; and households having outpatients and households headed by a minority person in Qinghai are more likely to experience the risk of CHE.

Conclusions: This study highlights the importance of improving economic development, expanding employment, and adjusting policies to make greater efforts to protect chronic diseases patients, outpatients, and inpatients, further to reduce the risk of $\mathrm{CHE}$. The Chinese government should pay more attention to the actual conditions in different provinces, further to make policy decisions according to the local knowledge.
\end{abstract}

Keywords: Catastrophic health expenditure, Household, Zhejiang province, Qinghai province, China

\section{Background}

The burden of health costs and the economic effect on households depend on the country's health system and the ability of out-of-pocket (OOP) expenditure of households [1]. Protecting the population against the financial risks associated with ill health is one of the fundamental objectives of the health systems [2]. Globally, there is an average of about $32 \%$ of each country's health expenditure from

\footnotetext{
*Correspondence: donghj@zju.edu.cn

${ }^{1}$ Center for Health Policy Studies, School of Public Health, Zhejiang University School of Medicine, Hangzhou, Zhejiang, China

Full list of author information is available at the end of the article
}

OOP payments [2]. It had estimated that approximately 150 million people globally are facing catastrophic expenditure annually because of high payments for health services [3]. Catastrophic health expenditure (CHE) is defined as OOP expenditure equaling to or exceeding $40 \%$ of household capacity to pay [4]. OOP expenditure and $\mathrm{CHE}$ are barriers to achieve universal health coverage [5], in which all people can obtain the health services they need without suffering financial hardship [6].

The health care reforms in China in the past aimed to establish a health system according with universal health coverage. There are three basic health insurances in

(c) The Author(s). 2018 Open Access This article is distributed under the terms of the Creative Commons Attribution 4.0 International License (http://creativecommons.org/licenses/by/4.0/), which permits unrestricted use, distribution, and reproduction in any medium, provided you give appropriate credit to the original author(s) and the source, provide a link to the Creative Commons license, and indicate if changes were made. The Creative Commons Public Domain Dedication waiver (http://creativecommons.org/publicdomain/zero/1.0/) applies to the data made available in this article, unless otherwise stated. 
China, including employer-based insurance, urban resident insurance, and new cooperative medical scheme. In recent years, many provinces have merge urban resident insurance and new cooperative medical scheme into urban and rural insurance [7]. Health insurance coverage has increased dramatically over the 20 years, from $30.2 \%$ in 1993 to $95.1 \%$ in 2013 [8]. The share of healthcare financing from OOP dropped from $59.97 \%$ in 2001 to $29.27 \%$ in 2015 [9]. However, the problems of expensive medical bills, difficult access to quality medical services, and poverty caused by diseases are still existing. The rate of CHE was $13.0 \%$ in China in 2008 [10], which is higher than some other countries [11-14]. Despite China's great achievements in health insurance coverage and healthcare financing, it falls short up to universal health coverage in a more comprehensive sense [10].

China contains vast territories and abundant resources, there remain some differences in life-style, national customs, medical conditions, and health consciousness. In addition, the processes of health care reform are wildly different in different provinces. It is necessary to provide targeted and practical suggestions based on the timely regional data.

As an important part of healthcare financing, a lot of studies focus on CHE. Most studies have measured the distribution and determinants of CHE in China [10, 14] and in other countries [11-13]. Some studies have explored CHE in one of provinces in China $[15,16]$. However, to our knowledge, very few studies have compared the occurrence and the performance of factors influencing CHE in two different provinces, China.

In this study, first objective is to quantify the extent of households faced CHE between Zhejiang and Qinghai, China. Secondly, it is aimed to identify the different performance of characteristics that affect households to incur health catastrophe in the two provinces. Thus, in designed the health systems, policy makers can make decisions according to the local knowledge that whether any characteristics are more vulnerable to $\mathrm{CHE}$.

\section{Methods}

\section{Data source and sampling}

The data used to calculate CHE were acquired from two household surveys conducted in Zhejiang in 2015 and Qinghai in 2016, which represent the eastern developed area and the western developing area, China.

Zhejiang, which covers $105,500 \mathrm{~km}^{2}$, is located in south-east coastal area of China, and had a population of about 5,539,000 and a Gross Domestic Product (GDP) of about the United States (US) \$ 1.23 trillion in 2015 $[9,17,18]$. It is an economically developed region in China. Since 2012, Zhejiang has steadily carried out the mechanism of "Double Sinking and Two Lifting" and sign contracts with general practitioners, deepened the reform of medical and health system, set up hierarchical medical system, and improved the ability of primary health care service. Qinghai, which covers $721,000 \mathrm{~km}^{2}$, is located in the west of China, and had a population of about 588,000 and a GDP of about US \$ 0.60 trillion in $2015[9,18,19]$. It is economically underdeveloped region in China. The minority nationalities accounted for $47.71 \%$ of the population in Qinghai, which has geographical characteristics and distinctive national features. Qinghai is enforce to implement initial diagnosis at primary health care institutions and two-way referral system, which closely combined between hierarchical medical system and the reform of medical insurance payment system [20]. Both Zhejiang and Qinghai are pilot provinces in overall health care reform nationwide [21], who play the important roles in health care reform and "healthy China".

Sampling on multi-stage stratified cluster random method was adopted in this study [15]. According to cluster analysis from the perspective of GDP, developed and underdeveloped areas in Zhejiang and Qinghai were randomly selected, and we added relatively developed areas in Qinghai due to the huge gap between the rich and the poor [22]. In the first stage, we randomly selected Jiashan county in jiaxing city and Jinyun county in Lishui city to represent developed areas and underdeveloped areas in Zhejiang. We randomly selected Chengxi district in Xining city, Pingan district and Huzhu county in Haidong city, and Jianzha county in Huangnan Tibetan autonomous prefecture to represent developed, relatively developed, and underdeveloped areas in Qinghai. In the second stage, we randomly selected one urban or one rural area from each county or district to represent street or village. In the third stage, based on the proportion of permanent residents, a number of households from each street or village were randomly sampled. Finally, there were two households with missing data and 19 households without health expenditures; thus, we exclude them, making the final sample size 1598 .

\section{Data collection and quality control}

According to the questionnaire in the Fifth National Health Services Survey, which has been shown to be consistent and reliable [10], we designed the questionnaire in this survey [8], including six parts: general household information, individual information, disease information in the last two weeks of survey, hospitalization information in the last one year of survey, patients' satisfaction and accessibility in basic medical facilities, and willingness of getting medical treatment. Face-to-face household interviews were conducted by qualified investigators with the great help of local health-related governments. Professors and postgraduate students in Zhejiang University were responsible for the strict quality control. 


\section{Indicators and data analyses}

In this study, the main indicator is $\mathrm{CHE}$, which occurs when the OOP payment for health care equals to or exceeds $40 \%$ of a household's income [15], which is related to capacity to pay of household, healthcare demand of household, and baseline characteristics of household head. Actually, some previous studies used household consumption expenditure rather than household income to calculate the rate of CHE. However, Chinese residents' saving rate is as high as $51.8 \%$ [15]. In other words, household income is greater than household consumption expenditure in most Chinese households. The capacity to pay would be underestimated and the rate of CHE would be overestimated, if household consumption expenditure were used to measure capacity to pay. Therefore, we used household income to measure household's capacity to pay in this study. There are two different ways about household income: disposable income of urban households and net income of rural households.

This study uses only a portion of the data gathered by the questionnaire. Based on the variables in the questionnaire and the main indicator in our study, we defined some new variables about household that may influence CHE. These included capacity to pay of household: household size, which is the number of permanent residents per household, household income per year, household consumption expenditure per year, household health expenditure per year, poor/low-insured household, which is the poor or low-insured household identified by the local government, proportion of members with health insurance in household; healthcare demand of household: number of members over 60 years in household, number of members with chronic diseases in household in the last six months, number of outpatients in household in the last two weeks of the survey, and number of inpatients in household in the last one year of the survey; and baseline characteristics of household head: residency, sex, nationality, marital status, which is marital status in the marriage law, educational status, and employment status.

First, we compared the characteristics of households and households with CHE between Zhejiang and Qinghai. $X^{2}$ or Fisher's exact test was used for categorical variables, and T-test or Manny-Whitney test was for continuous variables. Then, univariate logistic regression analyses were used to describe the effect of each factor on $\mathrm{CHE}$ and stepwise multivariate logistic regressions to explore the effect of factors on CHE. In the regression analyses, CHE was taken as the dependent variable, characteristics of households with CHE were taken as the explanatory variables. We assumed that all above variables have a positive association with $\mathrm{CHE}$, except household size, household income per year, and proportion of members with health insurance in household, and household headed by a man, a married person, or an employed person.

All expenses in our analysis were converted to 2015 US \$ values, using the consumer price index of China and the 2015 purchasing power parities [23, 24]. All tests were two-sided and a $p$-value $<0.05$ was deemed to indicate statistical significance. SPSS 21.0 was used for all statistical analyses.

\section{Results \\ Household characteristics}

A total of 1598 households were included in this study, including 995 in Zhejiang and 603 in Qinghai. Of these, the average rates of CHE in the two provinces, Zhejiang, and Qinghai were 17.5, 9.6, and 30.5\%, respectively.

Compared with households in Qinghai, households in Zhejiang were significantly associated with higher household income, and higher household consumption expenditure, but lower household health expenditure, and smaller household size and poor/low-insured household. Household heads in Zhejiang were more likely to be rural, be male, or be married status, but less likely to be minority or be illiteracy than those in Qinghai. On average, households in Qinghai were significantly associated with more members with chronic diseases in household and more inpatients in household, but fewer members over 60 years in household than those in Zhejiang. There were no significant differences between the two provinces in the aspects of proportion of members with health insurance in household and number of outpatients in household (Table 1).

\section{Household characteristics in relation to catastrophic health expenditure}

Compared with households with CHE in Qinghai, those in Zhejiang were significantly associated with higher household income, higher household consumption expenditure, higher household health expenditure, and more members over 60 years in household, but smaller household size. Households headed by a rural person in Zhejiang; and households headed by a minority person or an illiteracy in Qinghai were more likely to face CHE. There were no significant differences between the two provinces in the terms of poor/low-insured household, sex and married status of household head, proportion of members with health insurance, number of members with chronic diseases, outpatients and inpatients in household (Table 1).

\section{Factors influencing catastrophic health expenditure in univariate analysis}

In Zhejiang, all household characteristics were significantly associated with CHE, except three variables of 
Table 1 Household characteristics in Zhejiang and Qinghai province, China

\begin{tabular}{|c|c|c|c|c|c|c|c|c|}
\hline \multirow[t]{2}{*}{ Household characteristics } & \multicolumn{4}{|l|}{ Households } & \multicolumn{4}{|c|}{ Households with CHE } \\
\hline & $\begin{array}{l}\text { Total } \\
(n=1598)\end{array}$ & $\begin{array}{l}\text { Zhejiang } \\
(n=995)\end{array}$ & $\begin{array}{l}\text { Qinghai } \\
(n=603)\end{array}$ & $\overline{P \text {-value }}$ & $\begin{array}{l}\text { Total } \\
(n=280)\end{array}$ & $\begin{array}{l}\text { Zhejiang } \\
(n=96)\end{array}$ & $\begin{array}{l}\text { Qinghai } \\
(n=184)\end{array}$ & $P$-value \\
\hline Household with CHE, n (\%) & $280(17.5)$ & $96(9.6)$ & $184(30.5)$ & $<0.000$ & & & & \\
\hline Household income per year, mean (SE) (US \$) & $\begin{array}{l}17,430.06 \\
(459.00)\end{array}$ & $\begin{array}{l}21,539.81 \\
(539.19)\end{array}$ & $\begin{array}{l}10,648.63 \\
(752.56)\end{array}$ & $<0.000$ & $\begin{array}{l}6507.53 \\
(528.52)\end{array}$ & $\begin{array}{l}9462.44 \\
(1187.59)\end{array}$ & $\begin{array}{l}4965.83 \\
(477.67)\end{array}$ & 0.001 \\
\hline $\begin{array}{l}\text { Household consumption expenditure per year, } \\
\text { mean (SE) (US \$) }\end{array}$ & $\begin{array}{l}10,934.17 \\
(244.05)\end{array}$ & $\begin{array}{l}12,638.74 \\
(283.19)\end{array}$ & $\begin{array}{l}8121.48 \\
(423.20)\end{array}$ & $<0.000$ & $\begin{array}{l}8252.97 \\
(772.65)\end{array}$ & $\begin{array}{l}10,073.46 \\
(1168.00)\end{array}$ & $\begin{array}{l}7303.15 \\
(1000.57)\end{array}$ & 0.021 \\
\hline $\begin{array}{l}\text { Household health expenditure per year, mean } \\
\text { (SE) (US \$) }\end{array}$ & $\begin{array}{l}2204.33 \\
(121.62)\end{array}$ & $\begin{array}{l}2013.31 \\
(110.52)\end{array}$ & $\begin{array}{l}2519.53 \\
(265.40)\end{array}$ & 0.002 & $\begin{array}{l}5774.66 \\
(606.82)\end{array}$ & $\begin{array}{l}6912.54 \\
(798.13)\end{array}$ & $\begin{array}{l}5180.98 \\
(822.29)\end{array}$ & 0.022 \\
\hline Household size, mean (SE) & $3.04(0.03)$ & $2.86(0.04)$ & $3.35(0.06)$ & $<0.000$ & $3.19(0.09)$ & $2.53(0.11)$ & $3.54(0.11)$ & $<0.000$ \\
\hline Poor/low-insured household, n (\%) & $91(5.7)$ & $25(2.5)$ & $66(10.9)$ & $<0.000$ & $41(14.6)$ & $13(13.5)$ & $28(15.2)$ & 0.707 \\
\hline Rural household head, n (\%) & $859(53.8)$ & $583(58.6)$ & $276(45.8)$ & $<0.000$ & $181(64.6)$ & $71(74.0)$ & $110(59.8)$ & 0.019 \\
\hline Male household head, n (\%) & $1202(75.2)$ & $770(77.4)$ & $432(71.6)$ & 0.010 & $223(79.6)$ & $76(79.2)$ & $147(79.9)$ & 0.886 \\
\hline Minority household head, n (\%) & $171(10.7)$ & $14(1.4)$ & $157(26.0)$ & $<0.000$ & $80(28.6)$ & $3(3.1)$ & $77(41.8)$ & $<0.000$ \\
\hline Married household head, n (\%) & $1334(83.5)$ & $859(86.3)$ & $475(78.8)$ & $<0.000$ & $222(79.3)$ & $76(79.2)$ & $146(79.3)$ & 0.972 \\
\hline Educational status of household head, n (\%) & & & & $<0.000$ & & & & 0.001 \\
\hline Illiteracy & $166(10.4)$ & $56(5.6)$ & $110(18.2)$ & & $68(24.3)$ & $10(10.4)$ & $58(31.5)$ & \\
\hline Primary school & $448(28.0)$ & $305(30.7)$ & $143(23.7)$ & & $99(35.4)$ & $43(44.8)$ & $56(30.4)$ & \\
\hline Secondary school & $516(32.3)$ & $334(33.6)$ & $182(30.2)$ & & $71(25.4)$ & $29(30.2)$ & $42(22.8)$ & \\
\hline High/technical school or above & $468(29.3)$ & $300(30.2)$ & $168(27.9)$ & & $42(15.0)$ & $14(14.6)$ & $28(15.2)$ & \\
\hline Employment status of household head, n (\%) & & & & $<0.000$ & & & & 0.001 \\
\hline Employed & $1027(64.3)$ & $673(67.6)$ & $354(58.7)$ & & $134(47.9)$ & 38 (39.6) & $96(52.2)$ & \\
\hline Retired & $305(19.1)$ & $192(19.31)$ & $113(18.7)$ & & $61(21.8)$ & $22(22.9)$ & $39(21.2)$ & \\
\hline Unemployed & $266(16.6)$ & $130(13.1)$ & $136(22.6)$ & & $85(30.4)$ & $36(37.5)$ & $49(26.6)$ & \\
\hline $\begin{array}{l}\text { Proportion of members with health insurance } \\
\text { in household (\%),mean (SE) }\end{array}$ & $97.04(0.32)$ & $96.95(0.39)$ & $97.20(0.55)$ & 0.164 & $97.73(0.67)$ & $98.75(0.66)$ & $97.20(0.97)$ & 0.502 \\
\hline $\begin{array}{l}\text { Number of members over } 60 \text { years in } \\
\text { household, mean (SE) }\end{array}$ & $0.70(0.02)$ & $0.78(0.03)$ & $0.56(0.03)$ & $<0.000$ & $0.86(0.05)$ & $1.14(0.09)$ & $0.72(0.06)$ & $<0.000$ \\
\hline $\begin{array}{l}\text { Number of members with chronic diseases in } \\
\text { household in the last six months, mean (SE) }\end{array}$ & $0.39(0.02)$ & $0.33(0.02)$ & $0.48(0.03)$ & $<0.000$ & $0.74(0.05)$ & $0.74(0.08)$ & $0.74(0.06)$ & 0.963 \\
\hline $\begin{array}{l}\text { Number of outpatients in household in the } \\
\text { last two weeks of the survey, mean (SE) }\end{array}$ & $0.18(0.01)$ & $0.17(0.01)$ & $0.19(0.02)$ & 0.486 & $0.39(0.04)$ & $0.45(0.07)$ & $0.35(0.04)$ & 0.225 \\
\hline $\begin{array}{l}\text { Number of inpatients in household in the } \\
\text { last one year of the survey, mean (SE) }\end{array}$ & $0.24(0.1)$ & $0.17(0.01)$ & $0.34(0.02)$ & $<0.000$ & $0.63(0.04)$ & $0.63(0.07)$ & $0.63(0.05)$ & 0.967 \\
\hline
\end{tabular}

CHE catastrophic health expenditure; SE standard error; interquartile range; US United States

Household size: number of permanent residents in household; Poor/low-insured household: poor or low-insured household identified by the local government; Married: married status in the marriage law

$\mathrm{X}^{2}$ or Fisher's exact test was used for categorical variables, and T-test or Manny-Whitney test was for continuous variables

sex, nationality of household head, and proportion of members with health insurance in household. Household income, household size, household headed by a married person or an employed/retired person were protective factors for CHE. In Qinghai, all household characteristics were significantly associated with CHE, except four variables of marital status, educational status (secondary school vs high/technical school or above), employment status of household head, and proportion of member of health insurance in housheold. Household income per year is the only protective factor for CHE (Table 2).

\section{Factors influencing catastrophic health expenditure in} multivariate analysis

We found that the independent factors for households with CHE in both Zhejiang and Qinghai are household income, employed status of household head, number of members with chronic diseases in household, and number of inpatients in household; and the first two variables had negative effects on CHE. In addition, other independent factors for CHE in Zhejiang included poor/ low-insured household; for CHE in Qinghai were household headed by a minority person, and number of 
Table 2 Factors influencing catastrophic health expenditure in univariate logistic regression model

\begin{tabular}{|c|c|c|c|c|c|c|c|c|}
\hline \multirow[t]{2}{*}{ Variables } & \multicolumn{4}{|l|}{ Zhejiang } & \multicolumn{4}{|l|}{ Qinghai } \\
\hline & $b$ & S.E. & OR & $P$-value & $\mathrm{b}$ & S.E. & OR & $P$-value \\
\hline Household income per year & -0.0001 & 0.00001 & 1.000 & $<0.000$ & -0.0002 & 0.00002 & 1.000 & $<0.000$ \\
\hline Household size & -0.263 & 0.097 & 0.768 & 0.007 & 0.132 & 0.063 & 1.141 & 0.035 \\
\hline Poor/low-insured household & 2.449 & 0.416 & 11.577 & $<0.000$ & 0.588 & 0.267 & 1.800 & 0.028 \\
\hline Rural residency of household head & 0.764 & 0.242 & 2.147 & 0.002 & 0.818 & 0.181 & 2.266 & $<0.000$ \\
\hline Male household head & 0.116 & 0.264 & 1.122 & 0.661 & 0.625 & 0.212 & 1.868 & 0.003 \\
\hline Minority nationalities of household head & 0.957 & 0.660 & 2.604 & 0.147 & 1.115 & 0.194 & 3.049 & $<0.000$ \\
\hline Married household head & -0.575 & 0.270 & 0.563 & 0.034 & 0.050 & 0.218 & 1.051 & 0.819 \\
\hline \multicolumn{9}{|c|}{ Educational status of household head (reference: high/technical school or above) } \\
\hline Illiteracy & 1.491 & 0.443 & 4.441 & 0.001 & 1.719 & 0.282 & 5.577 & $<0.000$ \\
\hline Primary school & 1.210 & 0.319 & 3.353 & $<0.000$ & 1.169 & 0.269 & 3.218 & $<0.000$ \\
\hline Secondary school & 0.664 & 0.336 & 1.942 & 0.048 & 0.405 & 0.272 & 1.500 & 0.136 \\
\hline \multicolumn{9}{|l|}{ Employment status of household head (reference: Unemployed) } \\
\hline Employed & -1.856 & 0.258 & 0.156 & $<0.000$ & -0.415 & 0.215 & 0.661 & 0.054 \\
\hline Retired & -1.085 & 0.300 & 0.338 & $<0.000$ & -0.066 & 0.267 & 0.936 & 0.803 \\
\hline Proportion of members with health insurance in household & 0.021 & 0.015 & 1.022 & 0.146 & 0.00005 & 0.007 & 1.000 & 0.994 \\
\hline Number of members over 60 years in household & 0.448 & 0.113 & 1.565 & $<0.000$ & 0.346 & 0.108 & 1.414 & 0.001 \\
\hline $\begin{array}{l}\text { Number of members with chronic diseases in household } \\
\text { in the last six months }\end{array}$ & 0.907 & 0.141 & 2.476 & $<0.000$ & 0.749 & 0.127 & 2.115 & $<0.000$ \\
\hline $\begin{array}{l}\text { Number of outpatients in household in the last two weeks } \\
\text { of the survey }\end{array}$ & 1.086 & 0.181 & 2.962 & $<0.000$ & 1.016 & 0.191 & 2.763 & $<0.000$ \\
\hline $\begin{array}{l}\text { Number of inpatients in household in the last one year } \\
\text { of the survey }\end{array}$ & 2.150 & 0.230 & 8.588 & $<0.000$ & 1.654 & 0.195 & 5.227 & $<0.000$ \\
\hline
\end{tabular}

SE standard error; OR odds ratio

Household size: number of permanent residents in household; Poor/low-insured household: poor or low-insured household identified by the local government; Married: married status in the marriage law

outpatients in household. The most important independent factor for CHE in the two provinces was number of inpatients in household, followed by poor/low-insured household in Zhejiang and minority household head in Qinghai (Table 3).

\section{Discussion}

To the best of our knowledge, it is the first study to analyze the distribution and performance of factors of $\mathrm{CHE}$ in Zhejiang and Qinghai. It is also the first study to compare the differences of households with $\mathrm{CHE}$ in the two provinces, China.

CHE reflects the economic burden of households and the financial barriers to receive health care. In our study, households in Qinghai are at higher risk of experiencing CHE than households in Zhejiang. It may be closely related to regional economic development and healthcare demand in the two provinces. Total health expenditure in Zhejiang of about US \$ 65 billion was over ten times as many as those in Qinghai (US \$ 6 billion), total health expenditure per capita in Zhejiang was US \$ 113 higher than that in Qinghai, and household income in Zhejiang is two times higher than that in Qinghai [9]. Although total health expenditure account for GDP in Zhejiang was lower than that in Qinghai (5.25\% vs $8.93 \%$ ); and OOP payment as a share of total health expenditure in Zhejiang was relatively higher than that in Qinghai in 2015 (29.4\% vs $23.90 \%)$, they did not affect the higher rate of CHE in Qinghai [9] because of Zhejiang's GDP is twice that of Qinghai [18].

Low-income households and households headed by an unemployed person are more likely to suffer CHE, which are consistent with the findings in other studies $[10,12$, 14, 25]. Therefore, strategies that increase income among low-income households and narrow the income gap can be implemented, or efforts that improve the employment ability and brighten the employment environment should be made, further to reduce the effects of economic status or employment status for CHE, respectively [14].

The risk of $\mathrm{CHE}$ increased when the members in household in Qinghai went to hospital for outpatient or inpatient services. However, in Zhejiang, only inpatient services did affect the risk of CHE. It is reported that households with one or more inpatients or outpatients are at higher risks to encounter CHE because of the higher demands of health care [26]. However, residents 
Table 3 Factors influencing catastrophic health expenditure in multivariate logistic regression model

\begin{tabular}{|c|c|c|c|c|c|c|c|c|}
\hline \multirow[t]{2}{*}{ Variables } & \multicolumn{4}{|l|}{ Zhejiang } & \multicolumn{4}{|l|}{ Qinghai } \\
\hline & $\bar{b}$ & S.E. & OR & $P$-value & $\mathrm{b}$ & S.E. & OR & $P$-value \\
\hline Household income per year & -0.0001 & 0.00002 & 1.000 & $<0.000$ & -0.0002 & 0.00002 & 1.000 & $<0.000$ \\
\hline Poor/low-insured household & 1.797 & .507 & 6.029 & $<0.000$ & & & & \\
\hline Minority household head & & & & & 0.724 & 0.233 & 2.063 & 0.002 \\
\hline \multicolumn{9}{|l|}{ Employment status of household head (reference: unemployed) } \\
\hline Employed & -0.710 & 0.313 & 0.492 & 0.023 & -0.652 & 0.257 & 0.521 & 0.011 \\
\hline Retired & -0.149 & 0.394 & 0.861 & 0.704 & -0.180 & 0.325 & 0.835 & 0.580 \\
\hline Number of members with chronic diseases in household in the last six months & 0.528 & 0.182 & 1.695 & 0.004 & 0.452 & 0.161 & 1.572 & 0.005 \\
\hline Number of outpatients in household in the last two weeks of the survey & & & & & 0.505 & 0.231 & 1.657 & 0.029 \\
\hline Number of inpatients in household in the last one year of the survey & 1.752 & 0.232 & 5.764 & $<0.000$ & 0.859 & 0.186 & 2.361 & $<0.000$ \\
\hline (Constant) & -1.007 & 0.282 & 0.365 & $<0.000$ & -0.133 & 0.276 & 0.876 & 0.631 \\
\hline Model & $<0.000$ & & & & $<0.000$ & & & \\
\hline-2 log likelihood & 409.504 & & & & 550.674 & & & \\
\hline Nagelkerke $\mathrm{R}^{2}$ & 0.415 & & & & 0.384 & & & \\
\hline Cox \& Snell $R^{2}$ & 0.200 & & & & 0.272 & & & \\
\hline
\end{tabular}

SE standard error; OR odds ratio

Household size: number of permanent residents in household; Poor/low-insured household: poor or low-insured household identified by the local government; Married: married status in the marriage law

in developing regions who get access to outpatient service are at higher risk of experiencing CHE than those in developed regions. Therefore, policies for outpatients or inpatients should be adjusted according to the local conditions, for example, great efforts should be made to vigorously develop insurance for catastrophic illness in the two provinces, and adjust reimbursement ratio for outpatients in Qinghai, in order to reduce the rate of "poverty caused by diseases" [14].

Poor/low-insured households are at higher risk of experiencing CHE for households in Zhejiang, which is similar to other studies $[14,27,28]$. It is necessary to give greater government support for poor/low-insured households, especially in Zhejiang. In addition, households headed by a minority person are significantly associated with higher risk for CHE in Qinghai but not in Zhejiang. The minority nationalities accounted for about half of the population in Qinghai [19], who lives in hard-to-reach regions with abominable natural conditions, and works on agricultural and animal husbandry production. Besides, historical and social factors also restrict economy development among minorities in Qinghai [29]. According to the results in Chinese General Social Survey, household income of Han nationality was US $\$ 19,400$, US $\$ 12,892$ higher than that of minority nationalities; however, minority nationalities were associated with higher OOP for health care than Han nationality in China in 2014 [30]. It is reported that rapid population growth, and early marriage and early pregnancy are common in Qinghai, especially minority areas [29].
We found that health insurance did not significantly affect $\mathrm{CHE}$ in both univariate and multivariate analyses, which is similar to some studies [15, 31]. This demonstrates that health insurance, which mainly include three basic health insurances in China, actually have not reduced the risk of CHE. The weak performance of basic health insurance maybe related with the fact that almost residents in China are covered by basic health insurance [9]. Therefore, it is necessary to redesign basic health insurance or increase demand for commercial insurance in order to protect the households against CHE.

Some limitations of our study are worth noting. First, the data in our analysis is based on the remembrance of expenses in different time periods, which was taken to a weekly, monthly, or yearly unit for analysis, the actual prevalence of outpatients, inpatients and chronic diseases is probably higher than that reported in China. In addition, these results may not directly translate to other provinces in China; thus, future relevant studies in other provinces are needed.

\section{Conclusion}

The findings revealed that there are tremendous differences in the rates of CHE in Zhejiang and Qinghai. Economic status of households and households headed by an employed person are major protective factors for $\mathrm{CHE}$; and number of members with chronic diseases and number of inpatients in household are the risk factors for $\mathrm{CHE}$ in the two provinces. Besides, poor/low-insured household in Zhejiang; and households having outpatients and households headed by a minority person 
in Qinghai are more likely to experience the risk of CHE. Therefore, it is necessary to improve economic development, expand employment, and adjust policies to make greater efforts to protect chronic diseases patients, outpatients, and inpatients, further to reduce the risk of CHE. The Chinese government should pay more attention to the actual conditions in different provinces, further to make policy decisions according to the local knowledge.

\section{Abbreviations}

CHE: Catastrophic health expenditure; GDP: Gross domestic product; OOP: Out-of-pocket; US: United States

\section{Acknowledgements}

It is acknowledged that in the data collection, we obtained valuable help from government departments and health departments in Zhejiang province and Qinghai province. We also appreciate the help of all participants in this project.

\section{Funding}

This study was supported by National Natural Science Foundation of China (71573229).

\section{Availability of data and materials}

Please contact the corresponding author for data requests.

\section{Authors' contributions}

$X Z, H Z$, and HD participated the conception and design of the study, in the collection of data, performed the analysis and interpretation of data, drafted and revised the manuscript. $\mathrm{XH}, \mathrm{SG}, \mathrm{YL}, \mathrm{YG}, \mathrm{MH}, \mathrm{XS}$, and JW participated in the collection of data, the analysis of data, interpretation of data, revised the manuscript. All authors read and approved the final manuscript.

\section{Ethics approval and consent to participate}

This study was approved by the institutional review board of Zhejiang University School of Public Health.

\section{Consent for publication}

Not applicable.

\section{Competing interests}

The authors declare that they have no competing interests.

\section{Publisher's Note}

Springer Nature remains neutral with regard to jurisdictional claims in published maps and institutional affiliations.

\section{Author details}

${ }^{1}$ Center for Health Policy Studies, School of Public Health, Zhejiang University School of Medicine, Hangzhou, Zhejiang, China. ${ }^{2}$ Hangzhou Normal

University, Xuelin Street, Hangzhou, Zhejiang, China.

Received: 7 August 2018 Accepted: 29 October 2018

Published online: 09 November 2018

\section{References}

1. Wyszewianski L. Families with catastrophic health care expenditures. Health Serv Res. 1986:21:617-34

2. World Health Organization. The world health report 2000: health systems: improving performance. 2000. http://www.who.int/whr/2000/en/whr00_en. pdf?ua=1. Accessed 9 April 2018

3. Xu K, Evans DB, Carrin G, Aguilar-Rivera AM, Musgrove P, Evans T. Protecting households from catastrophic health spending. Health Aff (Millwood). 2007; 26:972-83

4. World Health Organization. The world health report 2013: research for universal health coverage. 2013. http://apps.who.int/iris/bitstream/handle/ 10665/85761/9789240690837 eng.pdf:jsessionid= 4F995BE6FD9C3FAA40BAF8DCF5FC38D5? sequence=2. Accessed 9 April 2018.
5. King G, Gakidou E, Imai K, Lakin J, Moore RT, Nall C, et al. Public policy for the poor? A randomised assessment of the Mexican universal health insurance programme. Lancet. 2009;373:1447-54.

6. World Health Organization. Tracking universal health coverage: 2017 global monitoring report. 2017. http://apps.who.int/iris/bitstream/handle/10665/ 259817/9789241513555-eng.pdf?sequence=1. Accessed 9 April 2018.

7. Sun X, Zhang H, Hu X, Gu S, Zhen X, Gu Y, et al. Measurement and analysis of equity in health: a case study conducted in Zhejiang Province, China. Int J Equity Health. 2018;17:36.

8. National Health and Family Planning Commission of the People's Republic of China. The Fifth National Health Services Survey. 2015. http://www.nhfpc gov.cn/ewebeditor/uploadfile/2016/10/20161026163512679.pdf. Accessed 7 Apr 2018

9. National Health Commission of the People's Republic of China. China Health Statistics Yearbook 2016. 2016. http://www.nhfpc.gov.cn/zwgkzt/tjnj/ list.shtml. Accessed 7 April 2018.

10. Li Y, Wu Q, Xu L, Legge D, Hao Y, Gao L, et al. Factors affecting catastrophic health expenditure and impoverishment from medical expenses in China: policy implications of universal health insurance. Bull World Health Organ. 2012;90:664-71.

11. Dorjdagva J, Batbaatar E, Svensson M, Dorjsuren B, Kauhanen J. Catastrophic health expenditure and impoverishment in Mongolia. Int J Equity Health. 2016;15:105.

12. Chuma J, Maina T. Catastrophic health care spending and impoverishment in Kenya. BMC Health Serv Res. 2012;12:413.

13. Yardim MS, Cilingiroglu N, Yardim N. Catastrophic health expenditure and impoverishment in Turkey. Health Policy. 2010;94:26-33.

14. Wang Z, Li X, Chen M. Catastrophic health expenditures and its inequality in elderly households with chronic disease patients in China. Int J Equity Health. 2015:14:8.

15. Gu H, Kou Y, Yan Z, Ding Y, Shieh J, Sun J, et al. Income related inequality and influencing factors: a study for the incidence of catastrophic health expenditure in rural China. BMC Public Health. 2017;17:727.

16. Yang T, Chu J, Zhou C, Medina A, Li C, Jiang S, et al. Catastrophic health expenditure: a comparative analysis of empty-nest and non-empty-nest households with seniors in Shandong, China. BMJ Open. 2016:6:e10992.

17. The People's Government of Zhejiang Province. About Zhejiang. 2016. http:// www.zi.gov.cn/art/2016/3/3/art_961 2061497.html. Accessed 7 Apr 2018.

18. National Bureau of Statistics of the People's Republic of China. China Statistics Yearbook 2016. 2016. http://www.stats.gov.cn/tjsj/ndsj/2016/ indexch.htm. Accessed 7 Apr 2018.

19. The People's Government of Qinghai Province. About Qinghai. 2016. http:// www.gh.gov.cn/dmah/glp/. Accessed 7 April 2018.

20. Chunli X, Mingqiang P. Current situation of and rethinking on the implementation of graded medical treatment system in China. Chin J Med Manag Sci. 2015;5:9-13.

21. The Central People's Government of the People's Republic of China. Pilot provinces in overall health care reform nationwide. 2016. http://www.gov. cn/xinwen/2016-05/13/content 5072915.htm.

22. Xing S. Income distribution is difficult at the start. 2010. http://www.docin. com/p-510312087.html. Accessed April 262018

23. Organisation for Economic Co-operation and Development. PPPs and exchange rates: purchasing power parities for GDP. 2015. https://stats.oecd. org/index.aspx?queryid=221\#.

24. Organisation for Economic Co-operation and Development. Consumer Prices (MEI). 2015. http://stats.oecd.org/index.aspx?queryid=221.

25. Adhikari SR, Maskay NM, Sharma BP. Paying for hospital-based care of kalaazar in Nepal: assessing catastrophic, impoverishment and economic consequences. Health Policy Plan. 2009;24:129-39.

26. World Health Organization. Defining and measuring fairness in financial contribution to the health system. 2000. http://www.who.int/healthinfo/ paper24.pdf. Accessed 10 April 2018.

27. Rahman MM, Gilmour S, Saito E, Sultana P, Shibuya K. Health-related financial catastrophe, inequality and chronic illness in Bangladesh. PLoS One. 2013;8:e56873

28. Bhojani U, Thriveni B, Devadasan R, Munegowda C, Devadasan N, Kolsteren $P$, et al. Out-of-pocket healthcare payments on chronic conditions impoverish urban poor in Bangalore, India. BMC Public Health. 2012:12:990.

29. Zhang Y. Influence of the traditional idea upon economy development in the minority nationality area in Qinghai. J of Qinghai Normal University (Philos and Soc Sci). 2003:4:10-3. 
30. Chinese National Survey Data Archive. Chinese general social survey 2015. 2015. http://cnsda.ruc.edu.cn/index.php?r=projects/view\&id=62072446. Accessed 10 Apr 2018.

31. Jiang C, Ma J, Zhang X, Luo W. Measuring financial protection for health in families with chronic conditions in rural China. BMC Public Health. 2012;12:988

Ready to submit your research? Choose BMC and benefit from:

- fast, convenient online submission

- thorough peer review by experienced researchers in your field

- rapid publication on acceptance

- support for research data, including large and complex data types

- gold Open Access which fosters wider collaboration and increased citations

- maximum visibility for your research: over $100 \mathrm{M}$ website views per year

At $B M C$, research is always in progress.

Learn more biomedcentral.com/submissions 